\title{
The Formation of Student Character through the Novel History of Pramoedya Ananta Toer in History Learning
}

\author{
Rudy Gunawan*, Desvian Bandarsyah \\ Program Studi S2 Pendidikan IPS \\ Universitas Muhammadiyah Prof. Dr. Hamka \\ Jakarta, Indonesia \\ *rudyansich@gmail.com
}

\author{
Wildan Insan Fauzi \\ Pendidikan Sejarah \\ Universitas Pendidikan Indonesia \\ Bandung, Indonesia
}

\begin{abstract}
Historical novels that are used together with textbooks and primary sources have made history learning more enjoyable. The function of historical novels is the resurrection of the past, namely the ability to revive the past which is the subject of the story and is able to provide historical information. Learning from past experiences can help shape the character of students to instill an understanding of the development of society past to the present, foster a sense of nationality and love of the homeland and have a sense of pride as citizens of Indonesia, and expand public relations between nations in the world. The novel discussed in this study is the work of Pramoedya Ananta Toer (Pram) entitled "Di Tepi Kali Bekasi". Pramoedya Ananta Toer was a writer who produced novels with a realistic and humanist approach. Pramoedya Ananta Toer wrote a book based on personal experience from the Dutch colonial period until the reformation era. In this study, the researcher describes what is the picture of the reality under study using historical research methods and literatur studies as research techniques. After studying the novel Pramoedya Ananta Toer, students can learn the characters that appear in novels such as the values of humanism, justice, divine values and arouse the spirit of life.
\end{abstract}

Keywords - history learning; novel history; pramoedya ananta toer; student character

\section{INTRODUCTION}

Historical writing and historical novels are different literary works at the time of delivery, especially in the disclosure of facts [1]. Suprapto explained that creation that can create a beautiful feeling for people who read and can feel it in terms of language and content is called literary work [2]. The disclosure of objective facts as possible without any imagination is called historical writing, while in historical novels the writer has a tendency to add imagination according to his will and ideas. Through the historical elements contained in it, literature and history can be connected factually. In addition, conceptually, literature and history can also be connected through intrinsic dimensions [3].

However, there are several novels that use factual data such as settings, recording of events and names of characters. This can make the reader enjoy a historical fact that is presented lightly, but the reader must be careful in distinguishing the elements of facts and fiction in them [2, 4]. In the world of education, historical novels function in terms of human formation and bring closer to the past of the nation [5].

The novel is able to provide a picture of life and examples of characters such as those conducted in research that analyzes character values, namely religious, tolerance, discipline, hard work, creative, respectful achievement, friendly/communicative, fond of reading, caring for the environment, caring socially, honest, independent, curiosity, and responsibility [6]. Other studies show that literature plays a major role in student character education in language, cognitive, personality and social development. Besides that, literary works can be used as catharsis media can be useful to teach receptive (accepting), expressive, self-character and exemplary abilities [7].

Description of historical events will arise historical awareness that can help students recognize their identity in terms of living together in a larger community, so as to foster a collective memory in having togetherness in history, togetherness in having a history of the past [8]. This process of self-recognition that increases into collective awareness is the starting point for the emergence of a sense of self-esteem, a sense of pride and a sense of belonging towards the nation and homeland [9]. The results of research on history learning show that students do not like history because it is boring and memorized, while those who like history because it can add insight, especially if the learning media uses games and videos [10].

In this study, researchers take a picture of the characters contained in the article Pramoedya Ananta Toer. The heuristic study conducted is a re-reading of Pramoedya Ananta Toer's book "Di Tepi Kali Bekasi" mold of 1995 [11]. Researchers try to find the characters that can be obtained from this novel.

\section{LITERATURE REVIEW}

\section{A. Character of Nation}

Character is a collection of one's character and character of the nation is a collection of the properties of the nation. Suryohadiprojo explains good and strong character are 
qualities that basically uphold the principles of ethics and morality, have virtuous character, persistence of attitude, honesty, courage, tenacious and tough. The virtuous nation is a nation that is faithful to its nationality and willing to do and run the best for the honor and dignity of its people [12]. Character education is absolutely necessary in every aspect of life such as at home, school and community as social environment [6]. In the guidebook of the Implementation of Character Education, the problems faced by the Indonesian nation are the disorientation of Pancasila values, the shift of ethical values, the threat of disintegration of the nation and the weakening of national independence $[13,14]$.

The values of character education consist of eighteen points, namely (1) Religious, (2) Honest, (3) Tolerance, (4) Discipline, (5) Hard work, (6) Creative, (7) Self, (8) Democracy, (9) Curiosity, (10) Spirit of nationality, (11) Love of the homeland, (12) Respect for achievement, (13) Friendly/ communicative, (14) Peaceful love, (15) Care for the environment, (17) Care for the social and (18) Responsible. In this study the character values to be discussed are courage, spirit of nationality, love of the homeland and honesty, so it can be a material that is able to shape the character of students after reading the history novel.

\section{B. Novel History}

Historical novels are novels that use historical facts, characters and events, space and time, as a background or elements that are more important by re-creating imaginatively and an attempt to understand the present through the past [5]. Historical novels are novels that tell a time in history and try to display the spirit of the times, manners, and social conditions of a past by elaborating in detail historical facts that seem realistic. Citing Wals' opinion, Hertz defines the historical novel "a novel is a historical novel when it is wholly or partly about the public event and social condition which is the material of history, regadless of the time at which it is writen" [15].

Historical novels are complex genres because they include fiction and nonfiction [16]. Historical novels are located at the intersection of fiction/nonfiction. Adult readers understand the complexity that exists in historical fiction, but it is not the case for students who have difficulty understanding the duality of historical fiction. Through the use of various approaches and strategies, teachers bring historical novels to their classes. Teachers need guidance if they will use historical novels in learning because this genre is complicated, through the intersection of nonfiction and fiction. With the development of well-written historical novel writing, teachers can find many stories to connect students with almost all historical events at any class level. Reading the type of narrative literature while studying the historical era, students will be able to deepen their understanding of the text by recognizing real or fictional characters in this book and understand why some historical figures act like them [17].

\section{Novel Pramoedya Ananta Toer}

Pramoedya Ananta Toer is a legendary writer who continues to write works of literature and has lived a long and arduous life and struggle. His life is spent more in prison [18].
Pramoedya is considered a writer with a socialist and godless stream, whereas in his literary works Pramoedya wrote more novels related to the values of humanism, justice, and divine values though not explicitly mention them [19]. Pramoedya can write works that can raise the spirits of someone who has been suppressed by power [20]. In some of his writings Pramoedya uses a diary technique. With that technique, events are displayed one at a time like a diary. The greatness of Pram with the technique is that each event is given its own narrative structure. The first item of the first short story is the reverse sequence of the narrative structure proposed by Toolan, which is opened in orientation and followed by an abstract [21].

A distinctive feature in Pram's work is to fight oppression, about humanity and justice [19]. No wonder in his novels Pramoedya discusses the lives of small people and tries to elevate their lives that seem neglected, criticize and highlight the depravity of "santri" who are insensitive to social problems, criticism of priyayi life and feudal life, justice, truth and humanity, criticizing the Javanese central government, criticizing social discrimination in the colonial era and complicated stratification and absolutism.

In this study, researchers took a picture of the national character contained in Pramoedya Ananta Toer's writing. Based on the discussion of Indonesianness in Pramoedya Ananta Toer's novel conducted by Sariban and Marzuqi [22], describing tolerance, respecting differences, loving the nation and state. In addition, the modernity of Indonesia is built with the tradition of continuing to learn, never giving up, being independent, brave to act and releasing dependence from other nations.

\section{Learning of History}

The curriculum developed for historical learning contains many innovations that change the position of historical education in many ways. The history education in the 2013 curriculum is designed as subjects that are full of historical skills and ways of thinking, developing national values, developing inspiration and linking national historical events with local historical events in a series of Indonesian history [23].

The importance of historical education is expressed by Abrahan Lincoln as "one can not escape history, one can not leave history" and Soekarno mentions in Gunawan [12]:

"Never leave history". this is the history of the struggle this is your history history. Hold on to your history, never leave your own history! Take hold of what we have now, which is the accumulation of the results of all our struggles in the past. If you abandon history, you will stand on a vacuum, you will stand above the emptiness and then you become confused, and will be a raging amok. Amok, like a monkey's naked in the dark. (Lecture of Bung Karno dated 17 August 1966.” [24].

Bung Karno's thoughts are grounded thoughts and can be absorbed in all circles. His more grounded thoughts are supported by the figure of Bung Karno as a polyglot who mastered the mother tongue, several ethnic languages of the archipelago, and several Western languages for international interaction, and his tactical struggle of Machtsvorming and 
Machtsaanwending with mass-action. After all Bung Karno is a master orator, master of choosing words that makes his listeners amazed to understand his ideas are intelligent and extraordinary. Soekarno also imagined that the proclamation of Indonesian independence as a golden bridge to the welfare and prosperity of Indonesia. Through the proclamation of the Indonesian people really take the fate of the nation and the fate of the homeland in the hands of oneself. Only a nation that dares to take its destiny in its own hands will be able to stand firmly to achieve the welfare of the Indonesian people. If the people are prosperous then historically, Indonesia will not experience disintegration.

In understanding the history of learners should know the history of his family, community, field ditekuni, history of the nation and the world. For that learners are required to actively ask and read not just listen passively historical facts that exist. Students are required to be involved in solving historical problems, hearing and reading historical stories, narratives, and literature meaningfully. In addition, learners can interview with the perpetrators of history, analyze documents, photos, historical records and historical sites [25].

\section{METHOD}

The research approach used is a qualitative approach in accordance with its purpose, namely to understand a humanitarian and social problem. The method used is historical research method with stages of heuristics, source criticism, and interpretation. The research subject, the novel entitled "Di Tepi Kali Bekasi" is a historiographic work and became the main data source in this study. Data analysis is carried out from specific to public with the intention of giving meaning to data, interpreting, transforming so as to produce findings and conclusions. Data taken from novels related to historical events, locations, character characterizations and historical objects. Then source criticism was carried out to obtain data validity.

\section{RESULT AND DISCUSSION}

The novel "Di Tepi Kali Bekasi" was one of the novels banned in its day by the reigning government at the time. This novel is written. in Jakarta on 13 January 1947. Initially the manuscript of this book was published under the title "KrandjiBekasi Djatoeh" in 1947 with the publisher of The Voice Free Indonesia in Jakarta. Prior to its publication in 1951, a portion of the manuscript was confiscated by Nefis, a Dutch intelligence organization in Indonesia so that at the time of publication by the Gapura NV Publishing Company, the book book Di Tepi Kali Bekasi was only $1 / 4$ of all posts from the previous book [11]. In the editorial note, Joesoef Isak, the republication of this book in 1957 is described by Pramoedya Ananta Toer "to remember the times of the Revolution where young men struggle with dashing officers without any preparation expressing struggle and growth in order that the book is re-published".

The whole book is based on the actual events, although it seems something is not aligned, it is because some of the records have been seized by the Dutch. Pramoedya Ananta Toer mentions that the extraordinary events experienced by
Bekasi have been going on throughout the ages, since the Dutch colonization until after the proclamation of Independence. Major events have occurred in Bekasi, since the colonial era of fighting against Dutch marsose with thousands of casualties falling and the people refused to give up tribute. During the Japanese occupation, Bekasi witnessed people's resistance to Japan, until the revolutionary period after the proclamation, there was a battle against the allied forces and NICA [11]. Pramoedya Ananta Toer was directly involved in the war in the Revolution and placed in Kranji and Bekasi. In Unity Pramoedya Ananta Toer gets the job of liaison. For Pramoedya Ananta Toer two places that have its own meaning so as to realize the talent and aspirations [20].

At the beginning of the story tells how Farid (the main character) remembers Bekasi as an imposing city in the heart. For Farid, Bekasi is a city that bounds. Bekasi is indeed a defensive area feared by British and Dutch soldiers during the Revolution of 1945-1946. The people of Bekasi have distinctive individual characteristics accompanied by strong historical roots that have the courage to fight against colonialism and imperialism [26].

Pramoedya Ananta Toer illustrates the Bekasi combat in detail, thus giving the reader a clear picture of Bekasi's devastating condition by the allied forces. Until for Pramoedya Ananta Toer "Bekasi city that borders". Nevertheless J.J. Rizal in a History Seminar entitled "Bekasi in the Revolution Period 1945-1949" organized by Historika Indonesia in collaboration with historical commands of Bekasi and Kamasa Bandung, explains "the important role of Bekasi people in the history of lack of place in general national history and history of West Java, photo documentation, Bekasi is a missing photo of West Java history album." [27]

Courage is what should be appreciated and become an example for students at this time. Students who do not have the courage will have less confidence so do not want to do anything, shy, not convinced by their own opinion, not ambitious and not responsible for the work done by the students [28]. Its application in learning history is the courage of students in expressing opinions. This courage is of course supported by the ability to communicate well, so that students are able to convey their ideas well.

The spirit of nationalism in this novel is described by Pramoedya Ananta Toer at the time of Bekasi City burned by allies of land and air using bombs, cannons and other modern tools. This burning incident has destroyed the homes of the people and spent their possessions. The phrase of this event is written by Pramoedya Ananta Toer on page 4:

"... All the goods they collect little by little, year after year completely destroyed. With the help of dozens of tanks and trucks and hundreds of soldiers they burned the hut and the people's building. Bekasi people can not forget this, although they do not want to regret the property that has perished and the house became a black stone ... [11]".

A sense of nationality is one of the forms of love of the country, defend the country and the spirit of patriotism [28]. The spirit of nationalism can be realized by learners in the learning of history by mutual respect, respect for difference and 
sacrifice at least for family and school. The spirit of nationalism will increase if there is a sense of social solidarity and willing to sacrifice. This can alleviate fears of threats and the collapse of national unity and unity.

The growing sense of nationality and love of the homeland will bring humanity into a civilized and cultured life. As revealed by Ki Hajar Dewantara, that education in human life is a "natural behavior" (instinct) so that it can be used as a medium of practice for students, giving guidance of the development of students' soul toward humanity and students can recognize the nature and natures own culture [29].

The dishonest feelings in the novel Pramoedya Ananta Toer are told on page 52, when Surip, one of the characters in the novel "On the Edge of Kali Bekasi" compares the services of Amir (other figures) who died in the battlefield of Kampung 2 Kranji Bekasi. In his novel was written "" Surip has been bowing his head. Not enforced. Perhaps he is comparing Amir's services with his cheating while working in Finance. Amir works really. He played serobot spending the Army's supplies ". Surip realized that he had been cheating. This cheating brings harm to his unity so that Surip feels shame and feels he has not done anything for his country.

In school, dishonesty is often exemplified by cheating behavior. Cheating becomes a problem because it has longterm impact. Lawson's results show that students who cheat when they are at school have a tendency to lie in the workplace [30]. In learning history, students can learn from the history of how a person is dishonest. The planting of honesty values can use a historical approach and the teacher's role is needed to convey historical events. The process of planting the value of honesty requires keteladan of teachers so that students do not lose the public figure and can develop personality in life [31].

\section{CONCLUSION}

The results show that the novel " Di Tepi Kali Bekasi " contains the values of characters that can be discussed in the learning of history and can be used as a companion book in learning history. The characters that appear give the color of its own character. The storyline is historical background, adding insight learners in obtaining historical understanding. In developing the character of the nation, the awareness of who he is and his nation can only be awakened through a history that provides enlightenment and an explanation of who his people in the past that produce the nation in this periode. In historical learning process, teachers should try to guide learners to more actively seek material about the nation's character values contained in the figure of a proclaimer so that learners can formulate questions, seek sources of information and gather information, process information, reconstruct data, facts or values obtained.

\section{ACKNOWLEDGEMENTS}

Acknowledgments to the Ministry of Research and Technology through the Directorate of Research and Community Service which has funded this research through a Competence Based Research scheme in 2018, Research
Institute of Muhammadiyah Prof. Dr. Hamka University, Jakarta and the Research Team.

\section{REFERENCES}

[1] Supriyadi, "Posmodernisme Linda Hutcheon: Poetics of Postmodernism (1989) dan Politics of Postmodernism (2002)," Jurnal Poetika, vol. IV, no. 2, pp. 129-133, Desember 2016.

[2] I. Rahayu, "Analisis Bumi Manusia Karya Pramoedya Ananta Toer dengan Pendekatan Mimetik," Deiksis Jurnal Pendidikan Bahasa dan Sastra Indonesia, vol. 1, no. 1, pp. 44-59, 2014.

[3] Arriyanti, "Sejarah dan Realitas Kekinian dalam Novel Rahasis Meede," Jurnal Metasastra, pp. 1-12, 2016.

[4] T.A. Bachtiar, "Muatan Nilai Islam dalam Penulisan Dan Pengajaran Sejarah,” Jurnal Pendidikan Agama Islam, pp. 201-218, 2016.

[5] A. Djokosujatno, "Novel Sejarah Indonesia: Konvensi, Bentuk, Warna, dan Pengarangnya," Makara Hubs-Asia, pp. 14-19, 2010.

[6] N.L. Dewi, I.B. Putrayasa, and I.G. Nurjaya, "Analisis Nilai-nilai Pendidikan Karakter Novel Sepatu Dahlan Karya Khrisna Pabichara dan Relevansinya terhadap Pengajaran Pendididkan Karakter Sekolah di Indonesia," e-Jurnal Pendidikan Bahasa dan Sasstra Indonesia, Undiksha, vol. 2, no. 1, pp. 1-10, 2014.

[7] R.A. Ningsih, "Sastra Dalam Pembentukan Karakter" Jurnal Edukasi Kultura, vol. 2, no. 2, pp. 63-73, 2015.

[8] R. Wiriaatmadja, Pendidikan Sejarah di Indonesia. Bandung: Historia Utama Press, FPIPS UPI, 2002.

[9] R. Gunawan, Pembelajaran Sejarah Berbasis Permainan Tradisional Betawi. Inovasi Pembelajaran Sebagai Upaya Meningkatkan Efektivitas Pembelajaran IPS, Bandung: Universitas Pendidikan Indonesia, 2012, pp. 387-395.

[10] T.A. Wijaya, A.P. Panama, and Y. Erina, Analisis dan Perancangan Game "The Proclamator", Jakarta: Universitas Bina Nusantara, 2011.

[11] P.A. Toer, Di Tepi Kali Bekasi, Jakarta: Hasta Mitra, 1995.

[12] R. Gunawan, "Pembelajaran Nilai-nilai Pahlawan Kemerdekaan Soekarno dalam Rangka Mengembalikan Karakter Bangsa Indonesia," E-Journal WIDYA Non-Eksakta, pp. 1-6, 2013.

[13] Kementerian Pendidikan Nasional, Panduan Pelaksanaan Pendidikan Karakter. Jakarta: Pusat Kurikulum, 2011.

[14] A.A. Tantri, "Nilai-nilai Pendidikan Karakter dalam Novel Tantri (Perempuan yang Bercerita) Karya Cok Sawitri sebagai Alternatif Pembelajaran Sastra di Sekolah Dasar," The 1st Education and Language International Conference, Semarang: Center for International Language Development of Unissula, 2017, pp. 57-68.

[15] S.K. Hertz, Using Historical Fiction in The History Classroom, New Haven: www.yale-new haven.edu, 2009.

[16] R. Barone, B. Oswalt, and D. Barone, "Historical Fiction through Fifth Graders' Eyes," Journal of Classroom Research In Literacy, 2014.

[17] C. Sliwka, "Connecting to History Through Historical Fiction," Language Arts Journal of Michigan, 2008.

[18] W. Fatmalia, H.E. Thahar, and N. Nurizzati, "Bias Gender dalam Novel," Bumi Manusia Karya Pramoedya Ananta Toer: Kajian Feminisme. Bahasa dan Sastra, pp. 12-21, 2012.

[19] A. Riyadi, Nilai-Nilai Profetik dalam Pemikiran Pramoedya Ananta Toer: Studi Literatur Roman Tetralogi Pulau Buru. (Skripsi. Yogyakarta: Fakultas Ilmu Sosial dan Humaniora UIN Sunan Kalijaga), 2016.

[20] S. Toer, Pram dalam Kelambu, Blora: PATABA Press, 2015

[21] S. Ghazali, Mengenal Wajah Indonesia melalui Penulis Realisme Sosialis Pramoedya Ananta Toer. Bahasa dan Seni, pp. 58-75, 2007.

[22] Sariban and I. Marzuqi, "Menemukan Keindonesiaan dalam NovelNovel Pramoedya Ananta Toer," Atavisme, vol. 18, no. 2, pp. 159-169, Desember 2015.

[23] Lampiran III Permendikbud Nomor 60, Pedoman Mata Pelajaran Sekolah Menengah Atas/Madrasah Aliyah. Jakarta: Kementerian Pendidikan dan Kebudayaan, 2014. 
[24] Perhimpunan Pelajar Indonesia Amiens, "Pemikiran Ucapan Tindakan Bung Karno", Retrieved from: http://ppiamiens.blogspot.com/2012/02/pemikiran-ucapan-tindakanbung-karno.html).

[25] R. Gunawan, "History of Indonesia Learning in Vocational High School: Developing Historical Thinking Skills of Students," The 2nd UNJ International Conference on Technical and Vocational Education and Training in 2015, Jakarta: Fakultas Teknik UNJ, 2015.

[26] Ismawati, Bekasi pada Masa Revolusi (1945-1949), Bandung: UIN Sunan Gunung Djati, 2011.

[27] Arsip Indonesia, "Melacak Jejak Sejarah Indonesia di Bekasi," Retrieved, from arsipindonesia.com: http://arsipindonesia.com/kronik/melacak-jejak-sejarah-indonesia-dibekasi/. Accesed November 19, 2017, Februari 2017.
[28] E. Rahayuningdyah, "Upaya Meningkatkan Kepercayaan Diri Melalui Layanan Konseling Kelompok Pada Siswa Kelas VIII D Di SMP Negeri 3 Ngrambe," JIPE, vol. 1, no. 2, pp. 1-14, 2016.

[29] B. Lestyarini, P"enumbuhan Semangat Kebangsaan untuk Memperkuat Karakter Indonesia melalui Pembelajaran Bahas," Jurnal Pendidikan Karakter, vol. 2, no. 3, pp. 340-354, 2012.

[30] F. Sukmawati, "Peran Kejujuran Akademik (Academic Honesty) dalam Pendidikan Karakter Studi Pada Mahasiswa Jurusan Bimbingan Konseling Islam Fakultas Ushuludin Adab dan Dakwah Angkatan 2013/2014,” Jurnal Khatulistiwa-Journal of Islamic Studies, vol. 6, no. 1, pp. 90-100, Maret 2016.

[31] Emosda, "Penanaman Nilai-nilai Kejujuran dalam Menyiapkan Karakter Bangsa,” Jurnal Innovatio, vol. X, no. 1, pp. 151-166, Januari-Juli 2011. 